\title{
Effects of maize and lucerne particle size on ruminal passage rate, chewing activity of cows in midlactation
}

\author{
Z.J. Cao, M. Ma, L.L. Wang, P. Chen and S.L. Li ${ }^{1}$ \\ State Key Laboratory of Animal Nutrition, College of Animal Science and Technology, \\ China Agricultural University \\ 100094 Beijing, P.R. China
}

\begin{abstract}
This study evaluated the effects of maize and lucerne particle size on ruminal passage rate and chewing activity in midlactation cows. Four multiparous Holstein cows with ruminal cannulas were assigned randomly to a $4 \times 4$ Latin square design. Treatments were arranged in a $2 \times 2$ factorial design; two lucerne particle sizes: $2.54 \mathrm{~mm}$ (short) and $6.22 \mathrm{~mm}$ (long) were combined with concentrates based on either ground maize $(711 \mu \mathrm{m})$ or cracked maize $(1755 \mu \mathrm{m})$. Diets were fed as a total mixed ration with a ratio of concentrate to forage of 39:61. No significant difference in dry matter intake, ruminal passage rate and chewing activity between ground maize and cracked maize were observed. Ruminal liquid passage rate increased from 11.3 to $12.1 \% / \mathrm{h}(\mathrm{P}=0.02)$ and ruminal solids passage rate tended to decrease from 6.4 and $6.0 \% / \mathrm{h}$ when short lucerne was fed to cows. Cows fed long lucerne hay spent more time ruminating compared to cows fed short lucerne hay $(\mathrm{P}<0.001)$. Total time spent on chewing by cows increased from 505 to $574 \mathrm{~min} / \mathrm{d}(\mathrm{P}=0.002)$ for short lucerne and long lucerne, respectively.
\end{abstract}

KEY WORDS: physical structure, lucerne hay, maize processing, ruminal digesta kinetics, ruminating activity

\section{INTRODUCTION}

The physical characteristics of feedstuffs become critical when attempting to define the lower limit for the acceptable ratio of concentrate and forage in dairy rations (Mertens, 1997). Maize is regarded as an optimal feedstuff due to its energy

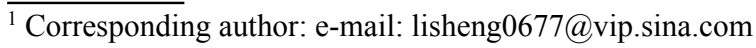


value, and lucerne hay has generally replaced maize stalks in diets fed in many of today's large and mechanized dairy farms in China due to its protein value, high digestibility and palatability.

Current recommendations for NDF, physically effective fibre (eNDF), and particle size distribution have primarily been established by high producing dairy cows in early lactation, and so were most studies that have examined maize processing. Little scientific research has evaluated how maize processing and lucerne chopping could be incorporated effectively into ration for lower producing dairy cows in midlactation. The ratio of concentrate and forage is different between early and middle lactation ration because of the nutrient requirements. There might be some varieties in physical structure of lucerne and maize processing. In fact, information is lacking concerning the effects of ground maize and short lucerne hay on ruminal passage rate and chewing activity in this stage of lactation.

\section{MATERIAL AND METHODS}

\section{Animals and nutrition}

Four multiparous Holstein cows were assigned randomly to a $4 \times 4$ Latin square design. Cows were fitted with ruminal cannulas $(10 \mathrm{~cm}$ in diameter, Bar Diamond, Parma, ID, USA), averaged $595 \mathrm{~kg}(\mathrm{SD}=52)$ of body weight and $141(\mathrm{SD}=21)$ days in milk at the start of the experiment. Experimental periods were $21 \mathrm{~d}$ in duration (14 d of treatment adaptation and $7 \mathrm{~d}$ of data collection). Diets were fed as a total mixed ration (TMR) (CAU-mixer wagon model JZC-200, Beijing, China) with a ratio of concentrate to forage of 39:61, offered three times daily at $07.30,13.30$ and $19.30 \mathrm{~h}$. TMR consisted of lucerne hay, maize silage, maize grain, wheat bran, soyabean meal, cottonseed meal, limestone, dicalcium phosphate, sodium chloride and vitamins-minerals mix, \%: 41.9, 19.4, 22.3, 4.22, 5.84, 3.71, $0.7,0.82,0.53,0.58$, respectively.

Treatments were arranged in a $2 \times 2$ factorial design; two levels of lucerne particle size were combined with concentrates based on either ground or cracked maize. Maize was ground through a hammer mill (Model No. 400, Yuanjing Co., Beijing, China). Geometric particle sizes of ground and cracked maize were $711 \mu \mathrm{m}(\mathrm{GM})$ and $1755 \mu \mathrm{m}(\mathrm{CM})$, respectively, according to ASAE procedures (1995). The lucerne hay was chopped with a forage chopper cutter (Model No. 93ZP-08, Fengcheng Co., Liaoning, China), and provided as short lucerne (SL, $2.54 \mathrm{~mm}$ ) and long lucerne (LL, $6.25 \mathrm{~mm}$ ) for the treatments, respectively. Particle size of lucerne hay was measured by Penn State Particle Separator (PSPS). 
Rumen pool size and rate of passage

Ruminal digesta kinetics was determined using Sodium-Co-EDTA and Crmordanted fibre prepared as described by Udén et al. (1980). Sodium-Co-EDTA and $\mathrm{Cr}$-mordanted fibre were used as markers for liquid and solid passage rates, respectively. Cr-mordanted fibre $(250 \mathrm{~g})$ and $500 \mathrm{ml}$ solution containing $15 \mathrm{~g}$ of Co-EDTA were inserted into the rumen via the rumen cannula before the time of the morning feeding. Faecal grab samples were taken at $0,6,10,14,18,22$, 26, 30, 36, 42, 48, 54, 60, 72, 84, 96 and $120 \mathrm{~h}$ after dosing (starting from d 15 ) to determine the rate of passage (Yang et al., 2002). Samples were dry-ashed and faecal marker concentrations of $\mathrm{Cr}$ and $\mathrm{Co}$ were determined by direct current plasma emission spectroscopy (Combs and Satter, 1992).

Before the morning feeding on the last day of each experimental period, rumen fill was determined by a complete rumen evacuation. After weighing and thorough mixing, two representative samples $(1 \mathrm{~kg})$ were taken. One sample was used to determine dry matter of ruminal contents, and the other sample was immediately separated into liquid and solid phases to determine proportion of liquid and solid by squeezing through four layers of cheesecloth. Ruminal contents left after sample collection were immediately placed back into the rumen.

\section{Chewing activity}

Eating and ruminating activities were measured by computer monitoring system (Infrared Monitor Apparatus, China Agricultural University, Beijing, China) during d 18, 19 and 20. Data were expressed as daily eating, ruminating, or total chewing activity. Total chewing time was calculated as the sum of total eating and ruminating time. This criterion was similar to the definition of eating described by Wangsness et al. (1976).

\section{Measurements and analyses}

In sampling period (from d 15 to 20) orts from each cow were gathered daily for calculation of DM and NDF intake. Dry matter of feeds was determined by ovendrying at $105^{\circ} \mathrm{C}$ for $16 \mathrm{~h}, \mathrm{OM}$ was determined by ashing at $550^{\circ} \mathrm{C}$ for $8 \mathrm{~h}$, and $\mathrm{CP}$ was determined by the micro-Kjeldahl method (AOAC, 1990). TMR and orts particle size were also measured by Penn State Particle Separator (PSPS, Heinrichs, 1996).

\section{Statistical analysis}

Data were analysed using the mixed model procedure of SAS (Proc MIXED; SAS, 2001). The effects of maize and lucerne particle size were considered fixed 
effects. The effects of cow and period were considered random. Significance was declared at $\mathrm{P} \leq 0.05$. A trend was considered to exist at $\mathrm{P} \leq 0.10$. All reported values are least square means unless otherwise stated.

\section{RESULTS AND DISCUSSION}

Total rumen pool size and dry matter of rumen contents were unaffected by any treatment (Table 1). This disagreed with the findings of Yang et al. (2002).

Table 1. Effects of maize and lucerne particle size on ruminal pool size and passage rate

\begin{tabular}{|c|c|c|c|c|c|c|c|c|}
\hline \multirow{2}{*}{ Item } & \multicolumn{2}{|c|}{$\mathrm{GM}^{1}$} & \multicolumn{2}{|c|}{$\mathrm{CM}$} & \multirow{2}{*}{ SEM } & \multicolumn{3}{|c|}{ P-value ${ }^{2}$} \\
\hline & SL & LL & SL & LL & & MPS & MPS & $\mathrm{C} \times \mathrm{M}$ \\
\hline \multicolumn{9}{|l|}{ Rumen pool size } \\
\hline total, $\mathrm{kg}$ & 73.3 & 71.2 & 70.0 & 70.2 & 2.97 & 0.48 & 0.77 & 0.72 \\
\hline DM content, $\%$ & 15.2 & 15.3 & 15.2 & 14.3 & 0.57 & 0.46 & 0.51 & 0.39 \\
\hline $\mathrm{DM}, \mathrm{kg}$ & 11.1 & 10.9 & 10.6 & 10.1 & 0.59 & 0.28 & 0.53 & 0.78 \\
\hline ruminal liquid passage rate, $\% / \mathrm{h}$ & 11.7 & 12.1 & 10.9 & 12.0 & 0.30 & 0.32 & 0.02 & 0.18 \\
\hline ruminal solid passage rate, $\% / h$ & 6.9 & 5.8 & 6.1 & 6.1 & 0.28 & 0.42 & 0.06 & 0.05 \\
\hline
\end{tabular}

${ }^{1}$ treatments: GM - ground maize, CM - cracked maize, SL - short lucerne. LL - long lucerne ${ }^{2}$ MPS - maize particle size, LPS - lucerne particle size, $\mathrm{M} \times \mathrm{L}$ - interaction of MPS and LPS

They observed that feeding ground lucerne hay rather than chopped lucerne hay reduced rumen pool size in high silage diets, and explained that rumen contents with chopped hay diet had a greater capacity to intake water. Cows usually stopped eating before reaching maximal ruminal capacity. Therefore the parameter of rumen fill sometimes doesn't seem to be a reliable indication of DMI. Ruminal liquid passage rate increased from 11.3 to $12.1 \% / \mathrm{h}(\mathrm{P}=0.02)$ when lucerne particle size (LPS) was changed from SL to LL and this was in agreement with finding of Krause et al. (2002). These authors explained that the increased ruminal liquid passage rate was probably because of a higher saliva production of cows fed coarse silage. Chewing activity was found to be higher for cows fed LL compared to SL, so a higher saliva production would be expected by cows fed coarse lucerne. In this study, the result were consisted with those obtained by Krause et al. (2002), that chewing activity increased when LPS changed from SL to LL.

Ruminal solids passage rate tended to decrease from 6.4 and $6.0 \% / \mathrm{h}$ for SL and LL ( $\mathrm{P}=0.06)$, respectively. An interaction between maize particle size (MPS) and LPS was significant $(\mathrm{P}=0.05)$. Ruminal solid passage rate increased when LPS changed from LL to SL in GM diets (5.8 and 6.9\%/h for GMSL and GMLL, respectively). According to Yang et al. (2002), decreasing forage particle size could decrease mean retention time for solids, and it allowed for a more rapid turnover of feed from the 
rumen. Mean passage rate of solids decreased with increasing LPS, which might be related to the fact that LL needed more chewing time.

Cows fed CM or GM had similar eating and ruminating time per day (Table 2).

Table 2. Effects of maize and lucerne particle size on chewing behaviour

\begin{tabular}{|c|c|c|c|c|c|c|c|c|}
\hline \multirow{2}{*}{ Item } & \multicolumn{2}{|c|}{$\mathrm{GM}^{1}$} & \multicolumn{2}{|c|}{$\mathrm{CM}$} & \multirow{2}{*}{ SEM } & \multicolumn{3}{|c|}{ P-value } \\
\hline & SL & LL & SL & LL & & MPS & LPS & $\mathrm{M} \times \mathrm{L}$ \\
\hline \multicolumn{9}{|l|}{ Eating } \\
\hline $\min / \mathrm{d}$ & 210 & 228 & 214 & 248 & 31 & 0.18 & 0.08 & 0.84 \\
\hline $\mathrm{min} / \mathrm{kg}$ of $\mathrm{DM}$ & 11.9 & 12.3 & 12.3 & 13.4 & 0.9 & 0.22 & 0.22 & 0.85 \\
\hline $\mathrm{min} / \mathrm{kg}$ of $\mathrm{NDF}$ & 32 & 30.8 & 31.3 & 35.6 & 5.5 & 0.28 & 0.29 & 0.61 \\
\hline \multicolumn{9}{|l|}{ Ruminating } \\
\hline $\min / \mathrm{d}$ & 285 & 331 & 301 & 340 & 26 & 0.43 & 0.04 & 0.34 \\
\hline $\mathrm{min} / \mathrm{kg}$ of $\mathrm{DM}$ & 16.1 & 17.8 & 17.2 & 18.4 & 1.6 & 0.46 & 0.003 & 0.42 \\
\hline $\mathrm{min} / \mathrm{kg}$ of $\mathrm{NDF}$ & 43.4 & 44.8 & 44 & 48.8 & 5.5 & 0.49 & 0.02 & 0.91 \\
\hline \multicolumn{9}{|l|}{ Chewing } \\
\hline $\min / \mathrm{d}$ & 495 & 559 & 515 & 588 & 25 & 0.17 & 0.002 & 0.67 \\
\hline $\mathrm{min} / \mathrm{kg}$ of $\mathrm{DM}$ & 28 & 30.1 & 29.5 & 31.8 & 1.9 & 0.24 & 0.02 & 0.74 \\
\hline $\mathrm{min} / \mathrm{kg}$ of $\mathrm{NDF}$ & 75.4 & 75.6 & 75.3 & 84.4 & 6.7 & 0.32 & 0.06 & 0.83 \\
\hline
\end{tabular}

${ }^{1}$ treatments: GM - ground maize, CM - cracked maize, SL - short lucerne, LL - long lucerne

${ }^{2}$ MPS - maize particle size, LPS - lucerne particle size, $\mathrm{M} \times \mathrm{L}$ - interaction of MPS and LPS

However, cows fed LL spent more time ruminating $(\mathrm{P}<0.001)$ compared to cows fed SL. Although the time spent eating was similar in SL and LL diets $(\mathrm{P}=0.18)$, total time spent chewing increased $(\mathrm{P}=0.002)$ for $\mathrm{LL}$ compared to SL. The time spent on ruminating per kilogram of DM and NDF intake was 16.7 min and 18.1 $\min (\mathrm{P}=0.003)$ and 43.7 and $46.7 \mathrm{~min}(\mathrm{P}=0.02)$ for $\mathrm{SL}$ and $\mathrm{LL}$, respectively. Consequently, there was a significant difference between SL and LL diets on total time spent on chewing per kilogram of DM and NDF intake. These results are consistent with the observations of Onetti et al. (2004), who reported that total time spent ruminating, as well as time spent ruminating per kilogram of DM and NDF intake was decreased for cows fed SL. Consequently, these results indicate that long lucerne hay is more effective in stimulating chewing activity. On the other hand, cows fed LL sorted against long particles rich in fibre in favour of fine feed particles, and likely resulting in less need for rumination. As eating time was similar for four diets, the result indicates that ingestive mastication expressed per kilogram of DM and NDF intake was more effective for LL than for SL. According to Mertens (1997), chewing activity was the animal response associated with physical effectiveness of fibre because it promotes salivary buffer secretion 
during eating and rumination. In this study, although ruminating and chewing time increased with the length of lucerne hay, a high ratio of lucerne hay to maize silage supplied sufficient eNDF in SL diets.

\section{CONCLUSIONS}

Dry matter intake, ruminal passage rate and chewing activity were not affected by ground or cracked maize. Short lucerne could increase ruminal liquid passage rate and tend to decrease ruminal solids passage rate. Cows fed long lucerne spent more time ruminating and chewing than cows fed short lucerne. Based on the results from this study, midlactation cows can be fed diets that contain ground maize and short lucerne without leading to negative effects on ruminal passage rate and chewing activity.

\section{REFERENCES}

AOAC, 1990. Association of Official Analytical Chemists, Official Methods of Analysis. 15th Edition. Arlington, VA

ASAE, 1995. Method of determining and expressing fineness of feed materials by sieving. In: Standards Amer. Soc. Agr. Eng., St. Joseph, MI

Combs D.K., Satter L.D., 1992. Determination of markers in digesta and feces by direct-current plasma emission-spectroscopy. J. Dairy Sci. 75, 2176-2183

Heinrichs J., 1996. Evaluating forages and TMRs using the Penn State Particle Size Separator. Penn State Cooperative Extension Service. DAS, pp. 96-20

Krause K.M., Combs D.K., Beauchemin K.A., 2002. Effects of forage particle size and grain fermentability in midlactation cows. II. Ruminal pH and chewing activity. J. Dairy Sci. 85, $1947-$ 1957

Mertens D.R., 1997. Creating a system for meeting the fiber requirements of dairy cows. J. Dairy Sci. $80,1463-1481$

Onetti S.G., Reynal S.M., Grummer R.R., 2004. Effect of alfalfa forage preservation method and particle length on performance of dairy cows fed corn silage-based diets and tallow. J. Dairy Sci. $87,652-664$

SAS, 2001. Release 8.01. SAS Institute Inc. Cary, NC

Udén P., Colucci P.E., Van Soest P.J., 1980. Investigation of chromium, cerium, and cobalt as digesta flow markers in rate of passage studies. J. Sci. Food Agr. 31, 625-632

Wangsness P.J., Chase L.E., Peterson A.D., Hartsock T.G., Kellmel D.J., Baumgardt B.R., 1976. System for monitoring feeding behavior of sheep. J. Anim. Sci. 42, 1544-1549

Yang W.Z., Beauchemin K.A., Rode L.M., 2002. Effects of particle size of alfalfa-based dairy cow diets on site and extent of digestion. J. Dairy Sci. 85, 1958-1968 